\title{
SOUTH WEST AFRICA CASES: PRELIMINARY OBJECTIONS
}

ETHropia and Liberia, in applications to the International Court of Justice, alleged that the Union of South Africa [South Africa] has violated Article 22 of the Covenant of the League of Nations and the terms of a Mandate under which it has responsibility for administering the Territory of South West Africa. Specifically the petitioning states charge that South Africa, in administering the territory, has practiced apartheid, has failed to promote to the utmost the material and moral well-being and social progress of the peoples of the territory, and has adopted and applied legislation and regulations which are arbitrary, unreasonable, unjust and detrimental to human dignity.

In this suit the petitioners seek to. give legal enforceability to an earlier advisory opinion of the Court which held that South Africa still has its international obligations, as stated in the Covenant and the Mandate, and the United Nations has the authority to exercise the supervisory functions relating to the Mandate. ${ }^{1}$ In its preliminary objections to the applications, South Africa submitted that Ethiopuia and Liberia had no standing in the Court and the Court had no jurisdiction to hear or adjudicate the matter. The Court held, however, that it has jurisdiction to adjudicate the action upon the merits. ${ }^{1 \mathrm{a}}$

\footnotetext{
1 International Status of South West Africa, Advisory Opinion, [1950] I.C.J. Rep. 128, 143. In 1949 the General Assembly of the United Nations submittcd several questions to the Court concerning the legal status of the territory of South West Africa with a request for an advisory opinion. After receipt of the opinion (cited above), the General Assembly, through a long series of resolutions, attempted to implement it. Subsequently, at the request of the General Assembly, two more advisory opinions were given by the Court relating to implementation of the Mandate. These advisory opinions, though they helped clarify the legal situation, were not technically binding on South Africa and the conflict between the General Assembly and South Africa concerning the Mandate grew sharper. Finally the Assembly, by resolution, suggested that member states might bring a contentious case against South Africa under the terms of the Mandate. In response to this suggestion Ethiopia and Liberia brought the present action. For citations to the advisory opinions and resolutions referred to herein, as well as for a more complete account of the South West Africa question, see Rosenne, The World Court, What It Is and How It Works, 150-51 (1962).

1a South West Africa Cases (Ethiopia v. South Africa; Liberia v. South Africa), Pre. liminary Objections, [1962] I.C.J. Rep. 319. The vote of the Court was eight to seven. Judge Jessup, of United States nationality, concurred in a separate opinion.
} 
Under the Treaty of Versailles, Germany relinquished all her overseas territories to the principal Allied and Associated Powers. The Powers, recognizing that the Leagne had a responsibility for these territories, allocated them as guardianships to various advanced Allied States to be exercised on behalf of the League. The purpose of the Mandates System was to recognize certain rights of the peoples concerned and to promote their well-being and development. To insure that this purpose was carried out, the system was fortified with a number of safeguards under which petitioners in the instant case now seek the aid of the Court.

In its objections, South Africa submitted: (1) that the Mandate was never, or at any rate since the dissolution of the League is no longer, a "treaty or convention in force" such as will bring the case within the jurisdiction of the Court; ${ }^{2}$ (2) that neither Ethiopia nor Liberia is "another Member of the League of Nations," as required for standing in the Court; ${ }^{3}$ (3) that the conflict or disagreement alleged to exist is not a "dispute" as envisaged in article 7 of the Mandate; and (4) that there have been no negotiations with a view toward settlement of the "dispute" as required by the Mandate. ${ }^{5}$

The Mandates, including the one for South West Africa, were drafted and approved by the Allied Powers in the autumn of 1919 , before the Covenant of the League of Nations took effect and before the League started functioning in Janaury 1920. In its judgment, the Court stated that the preamble of the Mandate makes it clear that the Mandate is, in fact and in law, an international agreement having the character of a "treaty or convention," between the Coun-

${ }^{2}$ Article 92 of the United Nations Charter provides that the Court shall function in accordance with the Statute of the Court which is an integral part of the Charter and is annexed thereto.

Article 37 of the Statute of the Court reads:

"Whenever a treaty or convention in force provides for reference of a matter to a tribunal to have been instituted by the League of Nations, or to the Permanent Court of International Justice, the matter shall, as between the parties to the present Statute, be referred to the International Court of Justice."

Thus the Statute provides for transition of jurisdiction from the former Court to the present one.

Article 7, para. 2 of the Mandate reads:

"The Mandatory agrees that, if any dispute whatever should arise between the Mandatory and another Member of the League of Nations relating to the interpretation or the application of the provisions of the Mandate, such dispute, if it cannot be settled by negotiation, shall be submitted to the Permanent Court of International Justice provided for by Article 14 of the Covenant of the League of Nations."

Ibid.

s Ibid. 
cil of the League of Nations, representing the League and its Members, and South Africa. ${ }^{6}$ Furthermore, the Court concluded that the Mandate is still in force, despite South Africa's contention that dissolution of the League necessarily extinguished the relationship between the parties to the Mandate. ${ }^{7}$ If the Mandate had lapsed, South Africa's authority to govern South West Africa would also have lapsed. Quoting from its advisory opinion of July 11, 1950, the Court said: "It cannot be admitted that the obligation to submit to supervision has disappeared merely because the supervisory organ has ceased to exist ...."8 More importantly, the member states of the League, prior to its dissolution, did not terminate the Mandates but definitely expressed the intention that they be continued. ${ }^{8 \mathrm{a}}$ Thus, although the League of Nations and the Permanent Court of International Justice both ceased to exist, South Africa's obligation

- The agreement to confer a Mandate on South Africa for the Territory of South West Africa was reached by a decision of the principal Allied Powers, including Great Britain, on May 7, 1919. It was agreed that His Britannic Majesty, "for and on behalf of the Government of the Union of South Africa," would undertake to exercise the Mandate on behalf of the League of Nations. On May 9, 1919, South Africa confirmed His Britannic Majesty's acceptance of the Mandate. A tentative agreement was then reached by the Allied Powers on the terms of the Mandate. This agreement was submitted to the Council of the League of Nations for its approval. On December 17, 1920, the Council and South Africa formally agreed to the Mandate and the terms exphicitly defined therein.

The fact that the Mandate provides that it shall be deposited in the archives of the League and that it shall be distributed by the Secretary-General to all signatories of the Treaty of Versailles "clearly implies that it was intended and understood to be an international treaty or convention embodying international engagements of general interest to the Signatory Powers ...." [1962] I.C.J. Rep. at 332. (Article 18 of the Covenant of the League of Nations provides that every treaty entered into by any Member of the League be registered with the Secretariat and published by it.)

"South Africa argued that although the rights and obligations relating to the administration of the territory are of an objective character and still exist, the rights and obligations relating to administrative supervison by the League, and submission of disputes under article 7 to the Permanent Court of International Justice were of a contractual character and are now extinct. [1962] I.C.J. Rep. at 332-33.

International status of South West Africa, Advisory Opinion, [1950] 1.C.J. Rep. $128,136$.

82 This intention was embodied in Chapter XII of the United Nations Charter which provides for establishment of an international trusteeship system to administer and supervise "such territories as may be placed thereunder by subsequent individual agreements," (article 75), including "territories now held under mandate...." (article 77). Thus, had South Africa chosen to do so, its authority to govern South West Africa could have been retained, after dissolution of the League, by converting the Mandate into a trusteeship agreement. But, desiring instead to annex South West Africa, it refused to do so. The Court, in its 1950 advisory opinion, declared that although Chapter XII does not impose on South Africa a legal obligation to place South West Africa under the trusteeship system, South Africa, acting alone cannot modify the international status of South West Africa, and that such can only be done with United Nations consent. [1950] I.C.J. Rep. at 144. 
to submit to the compulsory jurisdiction of that Court was effectively transferred to the present Court.

South Africa's second objection was that when the League ceased to exist all the member states necessarily lost their membership and today there can be no "Member of the League." However the Court said it was to effectively protest the "sacred trust" laid upon the League that the Mandates expressly provided for invocation of article 7 by any Member of the League. ${ }^{9}$ To read article 7 as South Africa suggested, the Court reasoned, would be to vitiate this essential judicial protection and would be incompatible with its spirit, purpose and context. Of more significance, continued the Court, article 7 remains applicable today because the members of the League agreed that it should remain applicable. It was their "common understanding" that the obligations of the Mandatory Powers and rights of the League Members should be continued so far as was practically feasible. ${ }^{10}$

Thirdly, South Africa contended that "dispute," as used in article 7 , means a disagreement or conflict between it and another Member of the League concerning the legal rights and interests of such other member, and that although the members, by virtue of their status in the League are entitled to participate in the supervision of the Mandate, they have no individual right or interest in the observance by South Africa of its duties to the inhabitants. But the Court said that the language of article 7 of the Mandate is "broad, clear and precise." It refers to any dispute whatever, relating to any of the provisions of the Mandate, whether the provisions relate to the obligations of South Africa toward the Territory's inhabitants, or toward other Members of the League, or to its obligation to submit to supervision by the League.

\footnotetext{
- Under the Covenant, the Council could not impose its own view on the Mandatory nor could either the Council or the League appear before the Court.

The Court stated that this right of a member to implead the Mandatory Power before the Permanent Court was specially and expressly conferred because it was considered to be the most reliable method of ensuring protection by the Court, whatever might happen to or arise from the machinery of administrative supervision. [1962] I.C.J. Rep. at 337-38.

${ }^{20} \mathrm{It}$ was on the basis of declarations of the Mandatory Powers as well as the views expressed by the other members that the League Assembly unanimously adopted a resolution embodying this understanding. The statement of South Africa before the Assembly said in part: "The Union Government will nevertheless regard the dis. solution of the League as in no way diminishing its obligations under the Mandate, which it will continue to discharge with the full and proper appreciation of its responsibilities ...." As quoted in [1962] I.C.J. Rep. at 340.
} 
Finally, South Africa submitted that there have been no negotiations with a view toward settlement of the dispute. The applicants replied that repeated negotiations have taken place for more than ten years under the auspices of the United Nations, and each time, the negotiations have reached a deadlock due to conditions and restrictions placed upon them by South Africa. In this light, the Court, feeling that the chances of success would be slight were there to be further negotiaticns between the present parties, concluded that a dispute now exists and is the same dispute which has been negotiated before the United Nations without success, and the impasse which was reached there continues to exist in the present case. "So long as both sides remain adamant, and this is obvious even from their oral presentations before the Court, there is no reason to think that the dispute can be settled by further negotiations between the Parties."11

The essence of the Mandates System concept is that states which undertake to govern dependent peoples not a part of such states have a responsibility to the international community for the wellbeing of such peoples. The effect of the judgment of the Court is to pave the way for a decision, which, if favorable to the petitioners, will give legal enforceability to this concept and to the views expressed in the earlier advisory opinion of the Court.

${ }^{11}$ [1962] I.C.J. Rep. at 346. 